\title{
VARIATION IN SOME FLEECE COMPONENTS OVER THE BODY OF HAMADANI SHEEP
}

\author{
Kasim O. Aziz \\ Ali H. Hamad
}

Dept. of Animal Resource, College of Agriculture, Univ.of Salahaddin, Erbil, Iraq

\begin{abstract}
The variation in some fiber properties at five sites / positions (shoulder, mid-side, hip, back and rump) over the body of Hamadani sheep were studied with 41 ewes. Staple length, fiber diameter, percentage of innercoat fibers and percentage of outercoat fibers were affected significantly $(\mathrm{P} \leq 0.01)$ by sampling site. Although, the pattern of variation was not consistent, the wool at hip position was longer and coarser than that from shoulder or mid-side positions. The shortest, finest and highest percentage of innercoat fibers were found on the back site. Since the mid-side position showed intermediate values among other four positions together with it's closer relations to the overall mean. Hence, the best compromise would be the use of mid-side position as the most suitable site for sampling Hamadani sheep fleeces.
\end{abstract}

\section{INTRODUCTION}

Sheep production is considered as the main activity of agricultural sector in Iraq, in particular in plain areas of Iraqi- Kurdistan, where Hamadani sheep are breed. These sheep belong to fat-tailed, carpet-wool group and their fleeces are characterized by being white in color except heads, necks \& legs which are black / brown or grayish. Furthermore, Hamadani sheep fleeces exhibited the most desirable characteristics for specialty carpet wool (Aziz \& Al-Oramary, 2005).

The lack of information about the pattern of variation of fleece components over the body of Hamadani sheep will hinder the determination of an optimum sampling position to assess the breeding value for potential replacement animals. In this regard, Doney \& Smith (1961a) observed large and highly significant variations in fleece components over the body of the Scottish Blackface sheep and it was concluded that the best site for sampling is the mid-side region. Recently, Tabbaa et al. (1998 \& 2001) have shown the significant effect of body location (shoulder, mid-side \& hip) on most fiber properties of Awassi sheep in Jordan. Therefore, the present study was conducted to investigate the regional variation of some fleece components and to establish the most suitable site for sampling Hamadani fleeces.

\section{MATERIALS AND METHODS}

Forty one Hamadani ewes, randomly selected from the Hamadani ewe flock, were sampled at five positions (shoulder, right mid-side, hip, back \& rump) on each sheep at shearing time in the late April, 2003 at the Grdarasha Farm, College of Agric., Univ. of Salahaddin-Erbil. All the animals had been run 
together during the previous twelve months. The sheep were housed in semi-open barns, with access to grazing green pasture from March to May and cereal stubble of wheat and barley crops from

Received 23/03/2006. accepted 14/6/2006

June to October. During the remainder of the year (late period of pregnancy \& early lactation) $500 \mathrm{~g}$ of ground black barley / ewe / day with a small amount of wheat straw were provided.

The average staple length of triplicate for each greasy wool sample was estimated, by a ruler, from their cut base to the midway in the pyramid formed by the tip (Von Bergen, 1963). The samples were scoured in water $\left(55^{\circ} \mathrm{C}\right)$ containing non-ionic detergent, rinsed and air-dried. Then staples were scoured by petroleum spirit and air-dried prior to any subsequent measurements. One hundred fibers were randomly drawn from a degreased staple and used for fiber length measurements. The diameters of 200 fibers were measured by projection microscope (Lanameter) from each sample in accordance to the ASMTT (1978). Also the weight of the different fiber types (innercoat, outercoat \& kemp fibers) were determined by visual separation of one degreased staple by applying the method of Doney and Smith (1961b).

The effect of sampling site on fleece components was determined using General Linear Model (SAS, 1989). Tests of significant differences between means of subclasses were carried out using Duncans Multiple Range Test.

\section{RESULTS AND DISCUSSION}

The mean and standard deviation values for staple length, fiber length, fiber diameter and fiber type ratio in each site are presented in Table ( 1 ).

The sampling site had a significant $(\mathrm{P} \leq 0.01)$ effect on staple length, fiber diameter and percentages of innercoat and outercoat fibers, while did not have a significant effect on fiber length and percentage of kemp fibers.

There was similarity in the gradients of staple length and fiber length, which tend to increase from the mid-side position towards the anterior and posterior positions. The rump site recorded the heighest lengths, while the back site showed the lowest staple length. Earlier researchers observed highly significant effect of sampling site on fiber length in Scottish Blackface sheep (Doney \& Smith, 1961a) and on staple length in Ossimi sheep (Saddick, 1993). Whereas, the effect of sampling site was not significant in Awassi sheep staple length (Tabbaa et al., 1998 \& 2001). In Blackface, the longest fibers were recorded on the shoulder then the mid-side and the shortest fibers were on the hip positions. In Ossimi, the shortest staples were recorded on the mid-side position. Conversely, in Awassi the longest fibers were found on the mid-side. 
The fiber diameter of shoulder and hip positions did not show any significant difference and the values of both sites were higher significantly $(\mathrm{P} \leq$ $0.05)$ than those obtained in rump and mid-side positions. The finest $(26.4 \mu \mathrm{m})$ and coarsest $(34.7 \mu \mathrm{m})$ fibers were recorded on the back and hip positions respectively. These results were in agreement with the findings of Doney \& Smith (1961a) for Blackface sheep. Similar results also were observed by Saddick (1993) for Ossimi sheep and by Tabbaa et al. (1998 \& 2001) for Awassi sheep. However in almost all breeds an anterior-posterior gradient of increasing fiber diameter has been demonstrated (Henderson \& Hayman, 1960; Doney \& Smith , 1961a; Ghoneim et al., 1968 and Tabbaa et al., 1998)

The back site had the highest percentage of innercoat fibers $(60.6 \%)$ and the lowest percentage of outercoat fibers $(34.4 \%)$. In turn this site produced finer fiber diameter. This was in agreement with findings observed by Aziz and AlOramary (2005). Wool on the shoulder had a similar percentage of fine fibers to that of the hip and both sites were lower than that of mid-side. This was in accordance to the results observed by Tabbaa et al. (1998) in Awassi sheep where mid-side had the highest percentage of innercoat fiber, whereas Tabbaa et al. (2001) for the same breed reported that the mid-side had the same value as hip and both sites were lower than that of shoulder. On the other hand, in Blackface sheep higher percentages of fine fibers were found on the shoulder and hip sites (Doney \& Smith, 1961a).

In general, in the present study fibers on the mid-side position were intermediate in their values among other four positions. The overall means of staple length, fiber length, fiber diameter, innercoat fibers, outercoat fibers and kemp fibers were $12.8 \mathrm{~cm}, 15.4 \mathrm{~cm}, 31.1 \mu \mathrm{m}, 52.1 \%, 42.7 \%$ and $5.2 \%$ respectively (Table 1). In this study, the obtained values for lengths were close to those reported by Ashmawy and Al-Azzawi (1982 a \& b), Maarof et al. (1982), Aziz (1993), Ali (1999) and Aziz \& Al-Oramary (2005) for the same breed. On the other hand the obtained values for fiber diameter and fiber type ratio were within the range obtained by the above researchers. In this occasion, it should be mentioned that Hamadani sheep were not selected for fleece characterestics as there were large variations in the fleece properties.

For all studied components a highly significant $(\mathrm{P} \leq 0.01)$ correlations existed between position means and overall mean (Table 2). The mid-side position, which is -

Table (2):Correlations between position values and overall mean for each fleece component.

\begin{tabular}{|c|l|l|l|l|l|}
\hline Positions & Shoulder & Mid-side & Hip & Back & Rump \\
\hline
\end{tabular}




\begin{tabular}{|l|c|c|c|c|c|}
\hline Staple Length & .83 & .85 & .91 & .76 & .74 \\
\hline Fiber Length & .73 & .84 & .87 & .74 & .84 \\
\hline Fiber Diameter & .85 & .83 & .79 & .72 & .65 \\
\hline Innercoat Fibers & .89 & .80 & .64 & .58 & .62 \\
\hline Outercoat Fibers & .80 & .81 & .72 & .68 & .67 \\
\hline Kemp Fibers & .59 & .66 & .74 & .72 & .74 \\
\hline
\end{tabular}

All correlations were highly significant $(\mathrm{P} \leq 0.01)$ 
Table (1):Means \pm standard errors of Hamadani fleece components at different sites.

\begin{tabular}{|l|l|l|l|l|l|l|l|}
\hline Variable & $\begin{array}{l}\text { Sampling } \\
\text { Size }\end{array}$ & $\begin{array}{l}\text { Staple Length } \\
(\mathrm{cm})\end{array}$ & $\begin{array}{l}\text { Fiber Length } \\
(\mathrm{cm})\end{array}$ & $\begin{array}{l}\text { Fiber Diameter } \\
(\mu \mathrm{m})\end{array}$ & $\begin{array}{l}\text { Innercoat Fibers } \\
(\%)\end{array}$ & $\begin{array}{l}\text { Outercoat Fibers } \\
(\%)\end{array}$ & $\begin{array}{l}\text { Kemp Fibers } \\
(\%)\end{array}$ \\
\hline $\begin{array}{l}\text { Sampling } \\
\text { Sites }\end{array}$ & $* *$ & NS & $* *$ & $* *$ & NS \\
\hline Shoulder & 41 & $12.6 \pm 0.33 \mathrm{~b}$ & $15.3 \pm 0.57$ & $33.8 \pm 1.08 \mathrm{a}$ & $45.1 \pm 2.51 \mathrm{c}$ & $50.0 \pm 2.97 \mathrm{a}$ & $5.0 \pm 0.75$ \\
\hline Mid-side & 41 & $11.9 \pm 0.30 \mathrm{~b}$ & $14.7 \pm 0.46$ & $29.3 \pm 0.79 \mathrm{~b}$ & $57.9 \pm 2.13 \mathrm{a}$ & $37.3 \pm 2.23 \mathrm{bc}$ & $4.9 \pm 0.51$ \\
\hline Hip & 41 & $13.7 \pm 0.39 \mathrm{a}$ & $15.5 \pm 0.52$ & $34.7 \pm 1.09 \mathrm{a}$ & $44.9 \pm 2.13 \mathrm{c}$ & $50.1 \pm 2.38 \mathrm{a}$ & $5.1 \pm 0.73$ \\
\hline Back & 41 & $11.7 \pm 0.33 \mathrm{~b}$ & $15.5 \pm 0.48$ & $26.4 \pm 0.56 \mathrm{c}$ & $60.6 \pm 1.53 \mathrm{a}$ & $34.4 \pm 1.87 \mathrm{c}$ & $5.0 \pm 0.78$ \\
\hline Rump & 41 & $14.0 \pm 0.33 \mathrm{a}$ & $16.0 \pm 0.54$ & $31.4 \pm 0.66 \mathrm{~b}$ & $51.9 \pm 1.51 \mathrm{~b}$ & $41.9 \pm 1.81 \mathrm{~b}$ & $6.2 \pm 0.65$ \\
\hline $\begin{array}{l}\text { Overall } \\
\text { Mean }\end{array}$ & 205 & $12.8 \pm 0.37$ & $15.4 \pm 0.52$ & $31.1 \pm 0.98$ & $52.1 \pm 2.22$ & $42.7 \pm 2.48$ & $5.2 \pm 0.69$ \\
\hline
\end{tabular}

$* * \mathrm{P} \leq 0.01$

NS=Non-significant

Values within the same column with different superscripts differ significantly $(\mathrm{P} \leq 0.05)$. 
most commonly used in single site sampling, was more closer to the overall mean than the other positions. This result corresponds with that observed by Doney \& Smith (1961a) for Scottish Blackface sheep.

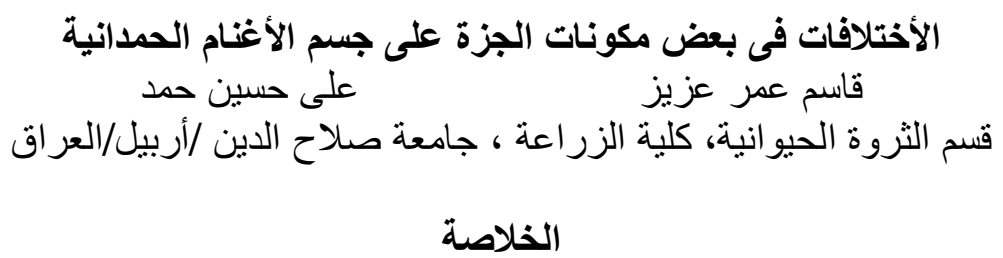

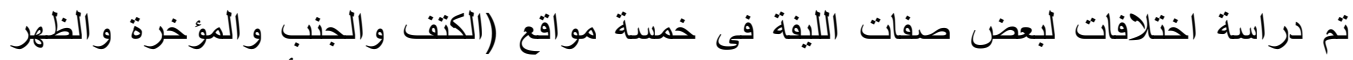

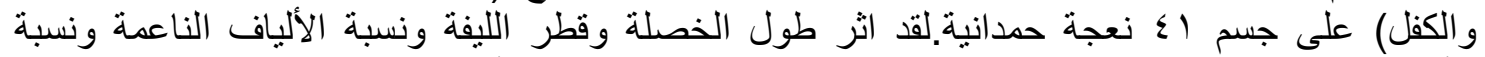

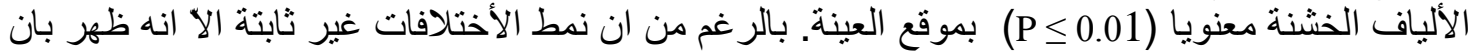
صوف المؤخرة كان اطول واخشن عن الكتف او الجنب. بينما وجدت الأنس الأقصر و الأنعم واعلى نسبة للألياف

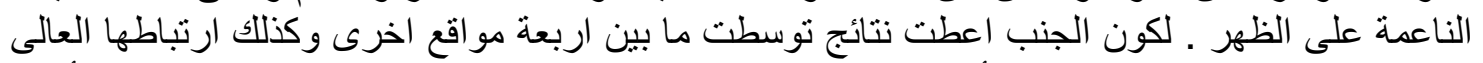

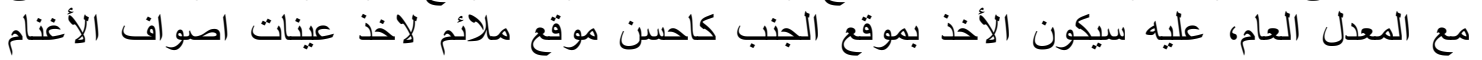
الحمدانية .

\section{REFERENCES}

Ali, S.H. (1999). Some genetic and non genetic effects on physical characteristics and fiber wool growth. Ph.D.Thesis, College of Agric., Univ.of Baghdad, Iraq.

Ashmawy, G.M. and W.A.Al-Azzawi (1982a). A Comparative study of fleece characterestics in Iraqi sheep, II.Fiber diameter, medullated fibers $\%$ and fiber length. Egypt. J.Anim.Prod., 22(1):63-71.

Ashmawy, G.M. and W.A.Al-Azzawi (1982b). A Comparative study of fleece characterestics in Iraqi sheep, I.Greasy -Fleece Weight, Shrinkage \% and Fiber Type Ratio. Egypt. J.Anim.Prod., 22(1):53-61.

ASMTT. (1978). Australian Standard Method of Test for Textile, A.S. 2001. 2.1, Determination of mean fiber diameter of textile fibers by projection microscope.

Aziz, K.O. (1993). Some wool quality traits of Hamadani sheep. Mesopotamia, J.Agric., 25(4):5-9.

Aziz, Kasim O. and Rabea A.S.Al-Oramary (2005). A study on fleece characterization of Hamadani sheep in Erbil plain. Mesopotamia, J.Agric., 33(1):3-12. 
Doney, J.M. and W.F.Smith (1961a). The fleece of the Scottish Blackface sheep. II.Variation in fleece components over the body of the sheep. J.Agric.Sci., 56:375-378.

Doney, J.M. and W.F.Smith (1961b). The fleece of the Scottish Blackface sheep. I. Seasonal changes in wool production and fleece structure. J.Agric.Sci., 56:365-374.

Ghoneim, K.E., G.E.M.Ashmawy and F.Al-Mekkawi (1968). Some wool characterestics of Awassi ewes. Mesopotamia, J.Agric.Res., 3(1/2):21-39.

Henderson, A.E. and B.I.Hayman (1960). Methods of analysis and the influence of fleece characters on unit area wool production of Romney lambs. Aust.J.Agric.Res., 11:851-870.

Maarof, N.N., A.M.Chakmakchy, K.S.Moustafa and B.P.Singh (1982). Preliminary studies on the wool quality traits of Hamadani sheep. $6^{\text {th }}$.Inter.Conf.on Anim.and Poultry Prod.Zagazig, Sept.21-23:478-487.

Saddick, I.M. (1993).Variation in some wool characterestics over the body of Ossimi sheep. Menofiya, J.Agric.Res., 18:1143-1155.

SAS. (1989). Statistical Analysis System. User's guide: Statistics.SAS.Inst. Cary, NC.USA.

Tabbaa, M.J.,W.A.Al-Azzawi and F.S.Al-Barakeh (1998). Effect of age and sampling location on fleece and fiber characterestics of Awassi sheep. Dirasat, Agricultural Sciences, 25(3):393-401.

Tabbaa, M.J.,W.A.Al-Azzawi and D.Campbell (2001). Variation in fleece characterestics of Awassi sheep at different ages. Small Ruminant Research, 41:95-100.

Von Bergen, W. (1963). Wool Handbook. $3^{\text {rd }}$ ed. V1. John Willy \& Sons Inc., New York, London :752. 